\title{
Hydrodynamic Condition of Tides and Wave Diffraction in the Estuary of Jeneberang River
}

\author{
Riswal Karamma ${ }^{1, a}$, Muhammad Saleh Pallu ${ }^{1, b}$, Muh. Arsyad Thaha ${ }^{1, c}$, Mukhsan Putra Hatta ${ }^{1 \mathrm{~d}}$ \\ ${ }^{1}$ Civil Engineering Department, Hasanuddin University, Makassar, Indonesia \\ a riswalchiwal@gmail.com \\ bsalehpallu@hotmail.com \\ c athaha199@yahoocom \\ dmukhsan.hatta@unhas.ac.id
}

\begin{abstract}
The coastal hydrodynamic pattern around the estuary is determined by the wave, river discharge, and the tidal condition which work simultaneously. The wave factor contributes to more dominant influence on estuaries located in the open sea. Wave coming towards the coast can generate current on the coast. The current pattern around the estuary is determined mainly by the magnitude of the angle formed between the incoming wave and the coastline. The objective of this research is to analyze the wave diffraction patterns and the length of tidal propagation towards the direction of the coast in the estuary. Investigated area is situated in the estuary of Jeneberang River. The analysis of tidal propagation and wave diffraction covers a reach of 4270 meters upstream. Data collected include bathymetric, wind, and tidal data. Furthermore, the result of this analysis can be used as an input in efforts to manage and develop the coastal area in the estuary of Jeneberang River. The length of the tidal propagation in the estuary of Jeneberang River is approximately 1220 meters upstream. Wave diffraction occurs from the north, northwest, and west direction. The highest wave diffraction came from the west direction with the value of $0.73 \mathrm{~m}$ and the lowest wave diffraction came from the north direction with the value of $0.04 \mathrm{~m}$.
\end{abstract}

Keywords—tidal; wave diffraction; estuary

\section{Introduction}

The propagation of tidal wave from the sea towards the estuary is directed opposite to the flow rate of the river that flows towards the sea. The difference in density between sea water and fresh water causes mixing between the two [1]. The degree of mixing depends on the geometrics condition of the estuary, tides, magnitude of the river flow rate, differences in density between sea water and fresh water, and wind [2]. The velocity of the tidal into the estuary depends on the depth of the water. Tides can cause horizontal current movements, which is the periodic horizontal flows of water associated with the tidal range. The current varies from zero when the water stops (slack water) to the maximum.
The hydrodynamic pattern of the coast around the estuary depends on the shape, characteristics and dominant factors that influence the morphology of the estuary itself [2]. These factors are wave, river flow rate, and tides [3]. Three of these factors work simultaneously, but usually one of these factors gives more dominant influence upon others.

Wave gives more dominant influence on smaller estuaries located in the open sea. On the contrary, larger estuaries in calm sea will be dominated by the flow rate of the river. Wave that is approaching towards the coast can generate coastal current that affect the dynamical process of the coast. The pattern of coastal current around the estuary is determined mainly by the magnitude of the angle formed between the incident wave and the coastline [4]. Dyer (1986) states that the modification of the shape of the coast around the estuary is a function of the influence of current along the coast which also influence the morphology of the coast in front of the estuary [5]. Current along the coast can be generated by breaking wave, forming an angle to the coastline [3]. Wave that propagates from deep waters to shallow waters will experience changes in wave characteristics and parameters such as the diffraction process, refraction process, shoaling, and reflection due to the influence of the characteristics and the shape of the coast. The coast always adjusts the shape of its profile in such a way that it can reduce the incoming wave energy. Some research works have been conducted on tidal- waves interaction [6], [7]. Other studies have also been undertaken in Jeneberang River, regarding the hydrodynamic modeling of its estuary [8], salinity distribution [9], water mass stratification [10], velocity distribution [11], sedimentation [12] as well as the tides on surf zone [13]. 


\section{Research Methodology}

The method used in this research is qualitative descriptive, then analysis will then be conducted in order to draw conclusions. The data used in this research includes the data of wind direction and speed, tides data, and also the topographic and bathymetry data of the research location obtained from ecmwf, wxtide32, Google Earth, tcx converter and navionics applications. Data analysis techniques used on this research consist of wind direction and speed analysis, effective fetch analysis, wave forecasting, breaking wave analysis, wave diffraction analysis, and tidal analysis. Wave that propagates from the sea to the coast experience changes in shape due to the influence of changes in the depth of the sea. The influence of the sea depth begins to take effect at depths smaller than half of the wave length. In the deep sea, the wave profile is sinusoidal, the closer it gets to the shallower water, the peak of the wave will get sharper and the through of the wave will get flatter. In addition, the speed and the length of the wave will gradually decreases while the wave height increases.

Breaking waves are affected by the slope, which is the ratio between the height and the length of the wave. In the deep sea, the maximum slope of the wave at which point the wave begin to become unstable is formulated by:

$$
\frac{H_{o}}{L_{o}}=\frac{1}{7}=0.142
$$

At this slope, the particle velocity at the peak of the wave is equal to the velocity of the wave. The slope that is sharper than the maximum limit $\left(\mathrm{H}_{0} / \mathrm{L}_{0}>0.142\right)$ causes the particle velocity at the peak of the wave become greater than the velocity of the wave, resulting in instability and breaking of the wave. When the wave moves toward the shallow sea, the slope boundary depends on the relative depth, $d / L$ and the slope of the sea bed $\mathrm{m}$. Wave from the deep sea that moves towards the coast will increase in slope until becoming unstable and break at that depth, which is called the depth of the breaking waves, $d_{b}$. The height of the breaking wave is designated as $H_{b}$. Formulas to determine the height and the steepness of the breaking wave are provided by USACE.

$$
\begin{gathered}
\frac{H_{b}}{H^{\prime}{ }_{o}}=\frac{1}{3.3\left(H_{o}^{\prime} / L_{o}\right)^{1 / 3}} \\
\frac{d_{b}}{H_{b}}=1.28
\end{gathered}
$$

$\mathrm{Hb} / \mathrm{Ho}^{\prime}$ is known as the breaking wave height index. The value of $\mathrm{Ho}^{\prime}$ is obtained from the division between $\mathrm{Hb}$ and the shoaling coefficient at depth $\mathrm{db}$. Another study proved that $\mathrm{Hb} / \mathrm{Ho}$ ' and $\mathrm{db} / \mathrm{Hb}$ depends on the slope of the coast and the slope of the incident waves [14]. The determination of the height and the depth of the breaking wave can be done by making a superposition diagram between the wave height affected by the shoaling and refraction process with a wave height diagram that is affected by the depth of the water[15]. In this case, it is considered that the height of the breaking wave is proportional to the depth of the water, meaning that the height of the breaking wave is equal to 0.78 of the water depth The Admiralty method is utilized to calculate the tides, which will obtain the highest high water level (HHWL), high water level(HWL), mean water level (MWL), low water level (LWL) and lowest low water level (LLWL). The type of tides in the study location can be determined by calculating the value Formzhal Number (FN)[16].Wave diffraction occurs when the incident wave is blocked by an obstacle such as breakwater or an island. The wave will subsequently turn around at the end point of the obstacle and enter the protected area behind it. Diffraction occurs when the wave height at a point on the wave crest is greater than a nearby point, which causes energy transfer along the wave crest towards the direction of a smaller wave height [17].

\section{Results and Discussion}

The analysis result of the topography and the bathymetry data at the research location is shown in Figure 1. 


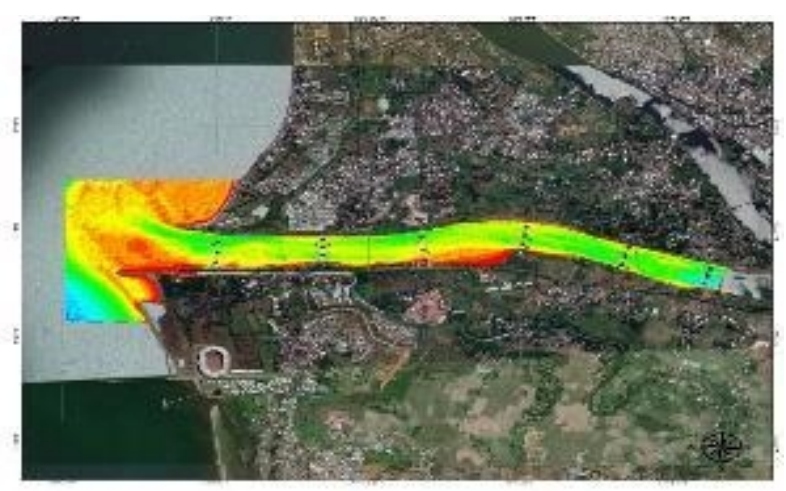

Figure 1. Topography and bathymetry map of the research location

It is apparent that the most wind events that occur at the research location came from the southeast direction. The sum of the data for this event is 5355 with the percentage of the wind event is approximately $33.31 \%$, followed by from the east, west, northwest, south, southwest, northeast, and north direction. The wind rose diagram of the research location is shown in Figure 2.

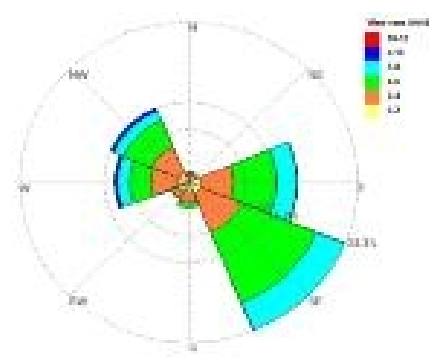

Figure 2. Wind rose diagram of the research location

The mapping result of the measurement and calculation of the effective fetch at the research location is shown in Figure 3.

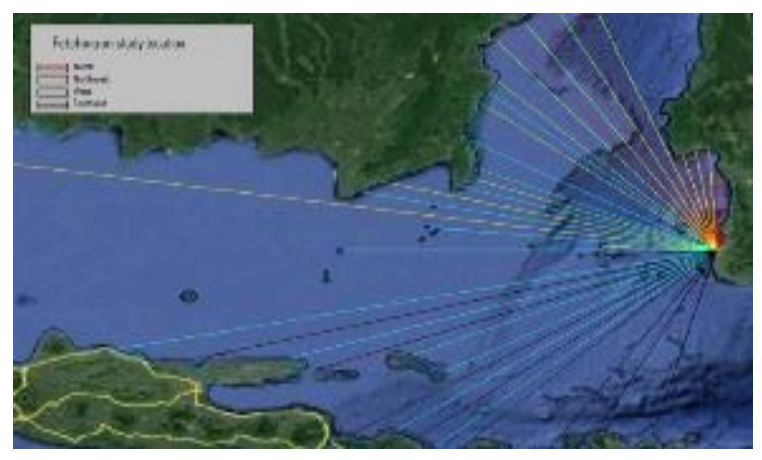

Figure 3. Effective fetch measurement map of the research location
The result of the wind data and effective fetch analysis can then be used to proceed with the wave forecasting. The most wave events in the research location came from the northwest direction with 2719 data with the percentage of wave events is approximately $45.01 \%$, followed by west, southwest and north direction. Meanwhile, there is no potential for wave coming from the northeast, east, southeast, and south direction because these directions are blocked by the land area of the research location.

The wind rose diagram of the research location is shown in Figure 4.

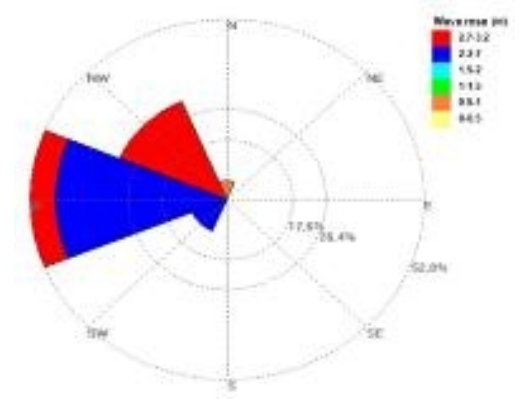

Figure 4. Wave rose diagram of the research location

Based on the result of the sea wave period data analysis with various return period and depth, the wave length (L) for each depth (d) can then be calculated and the result is shown in Table 1.

Table 1. Wave length for various depth and wave incident direction

\begin{tabular}{|c|c|c|c|c|c|}
\hline \multirow{2}{*}{ No } & \multirow{2}{*}{$\begin{array}{c}\text { Depth } \\
\text { (d) }\end{array}$} & \multicolumn{4}{|c|}{ Wave length (L) } \\
\hline & & North & Northwest & West & Southwest \\
\hline 1 & 0.05 & 3.2 & 5.4 & 6.3 & 5.5 \\
\hline 2 & 0.1 & 4.5 & 7.6 & 8.8 & 7.8 \\
\hline 3 & 0.25 & 7.1 & 12.0 & 14.0 & 12.3 \\
\hline 4 & 0.5 & 10.0 & 17.0 & 19.7 & 17.4 \\
\hline 5 & 0.75 & 12.1 & 20.7 & 24.1 & 21.2 \\
\hline 6 & 1 & 13.8 & 23.9 & 27.7 & 24.5 \\
\hline 7 & 1.5 & 16.7 & 29.1 & 33.8 & 29.8 \\
\hline 8 & 2 & 18.9 & 33.4 & 38.9 & 34.2 \\
\hline 9 & 3 & 22.4 & 40.4 & 47.2 & 41.5 \\
\hline 10 & 4 & 24.9 & 46.1 & 54.1 & 47.3 \\
\hline 11 & 5 & 26.9 & 50.9 & 59.9 & 52.3 \\
\hline 12 & 7.5 & 29.9 & 60.5 & 71.8 & 62.2 \\
\hline
\end{tabular}


The determination of the height and the depth of the breaking wave can be done by making a superposition diagram between the wave height affected by the shoaling and refraction process with a wave height diagram that is affected by the depth of the water. The breaking wave analysis result in the research location is shown in Figure 5.
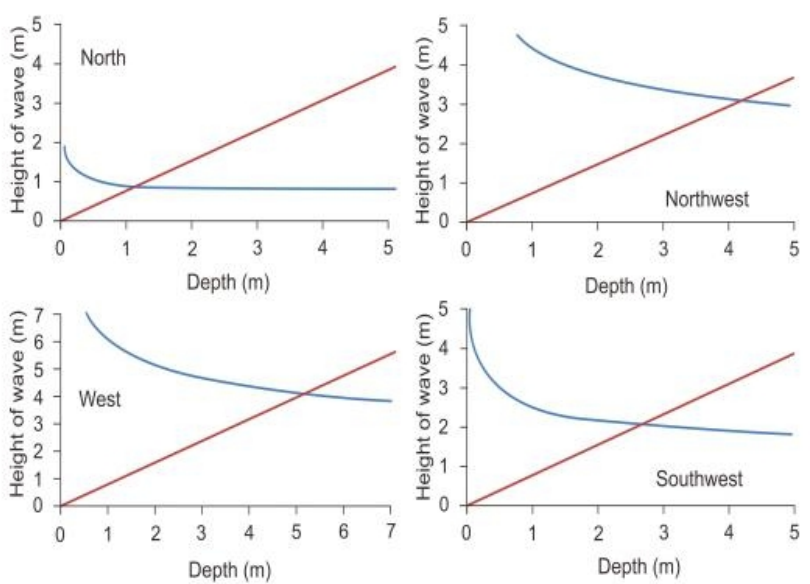

Figure 5. Breaking wave diagram in Jeneberang River Estuary from various directions

For further details regarding to the data, the height and the depth of the breaking wave at the research location can be seen in Table 2 .

Table 2. Height of the breaking wave, $\mathrm{H}_{\mathrm{b}}$ and depth of the breaking waves, $d_{b}$ in the research location

\begin{tabular}{cccc}
\hline \multirow{2}{*}{ No } & \multirow{2}{*}{ Direction } & \multicolumn{2}{c}{ Jeneberang Estuary } \\
\cline { 3 - 4 } & & $\mathbf{H}_{\mathbf{b}}$ & $\mathbf{d}_{\mathbf{b}}$ \\
\hline 1 & $\mathrm{~N}$ & 0.90 & 1.2 \\
2 & $\mathrm{NW}$ & 3.20 & 4.3 \\
3 & $\mathrm{~W}$ & 4.00 & 5.2 \\
4 & $\mathrm{SW}$ & 2.00 & 2.65 \\
\hline
\end{tabular}

Based on the topography and the bathymetry data, and also the tidal data obtained from 15 days of observation, an analysis is then conducted in order to determine the tidal constants. The Admiralty method is used for this analysis. The result of the tidal harmonic constants is shown in Table 3 and Table 4.
Table 3. Analysis result of the tidal harmonic constants

\begin{tabular}{cccccc} 
A (cm) & S0 & M2 & S2 & N2 & K1 \\
\cline { 2 - 6 } & $\mathbf{9 7 . 6}$ & $\mathbf{5 1 . 2}$ & $\mathbf{1 9 . 1}$ & $\mathbf{8 . 3}$ & $\mathbf{1 2 . 6}$ \\
\hline $\mathrm{g}^{0}$ & 0.0 & 77.4 & 230.2 & 264.3 & 88.5 \\
\hline
\end{tabular}

Table 4. Analysis result of the tidal harmonic constants

\begin{tabular}{cccccc}
\hline A (cm) & O1 & M4 & MS4 & K2 & P1 \\
\cline { 2 - 6 } & $\mathbf{8 . 5}$ & $\mathbf{1 . 8}$ & $\mathbf{2 . 2}$ & $\mathbf{5 . 2}$ & $\mathbf{4 . 1}$ \\
\hline $\mathrm{g}^{0}$ & 195.7 & 125.6 & 293.6 & 230.2 & 88.5 \\
\hline
\end{tabular}

The comparison between the directly recorded water level elevation and the calculation result of the water level elevation is presented with a diagram shown in Figure 6.

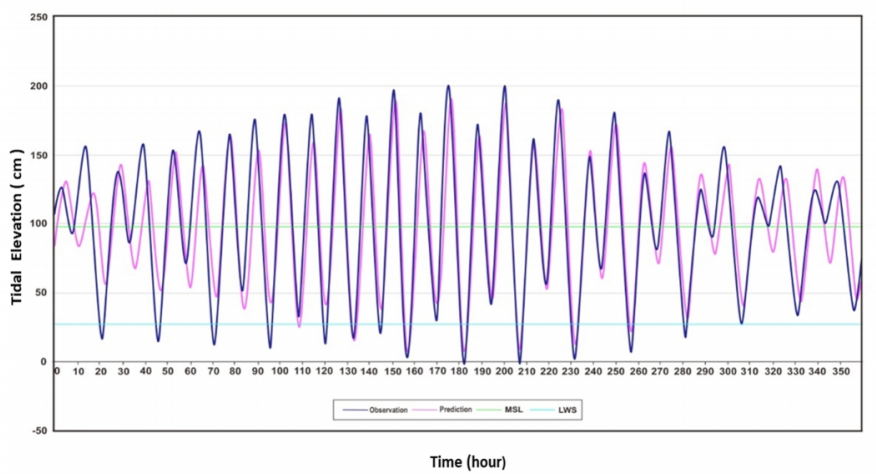

Figure 6. Water level elevation diagram in the research location

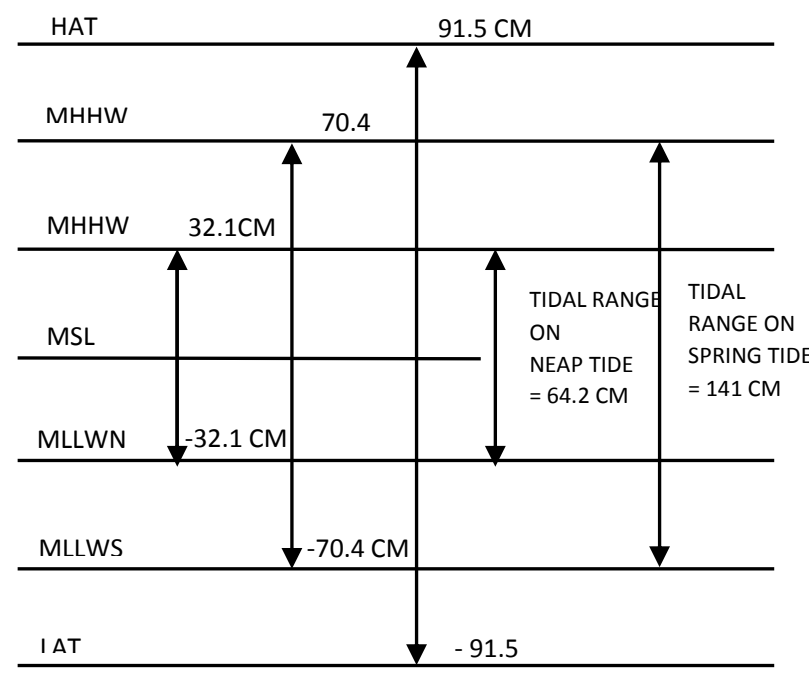

Figure 7. Tidal range in the research location 
From the figure above, it can be seen that on the spring tide, the tidal range could reach up to $141 \mathrm{~cm}$. By knowing the tidal range, the length of the tidal propagation of sea water in the research location can be determined. Based on the analysis result, the length of the tidal propagation can only reach up to 3 inspection points or the propagation length from the estuary is approximately 1220 meters. The tidal elevation at each inspection point that is affected by the propagation is shown in Figure 9.

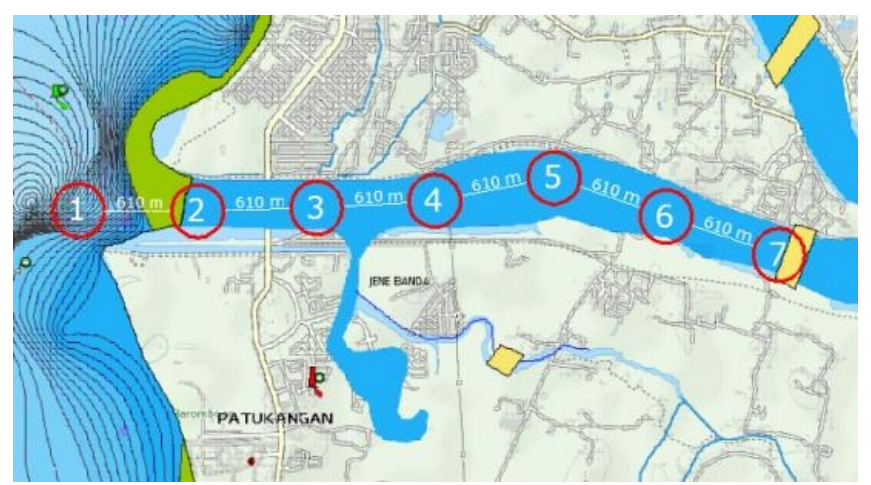

Figure 8. Inspection points of the tidal propagation

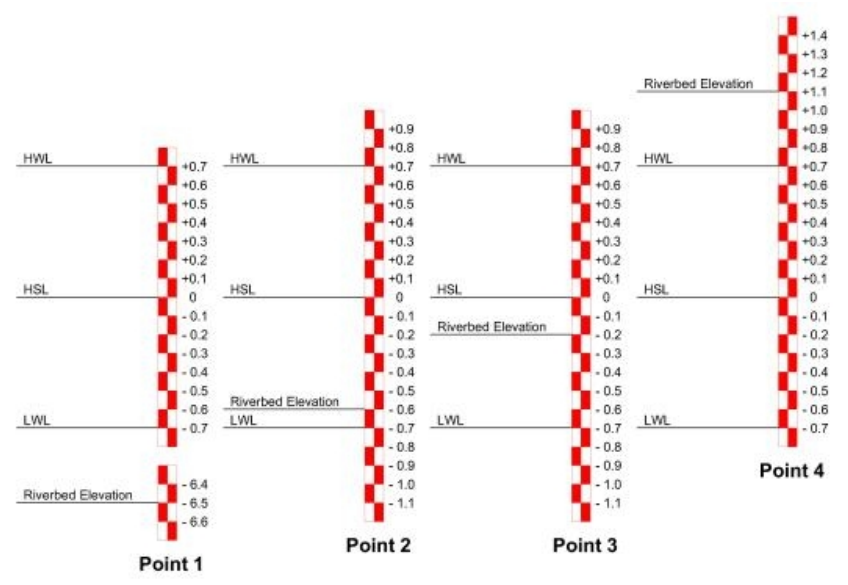

Figure 9. Tidal elevation at inspection points

By using the analysis results above, the wave diffraction in the research location can then be calculated and the results can be seen in Table 5 to Table 8 , and figure 10 to figure 13 .

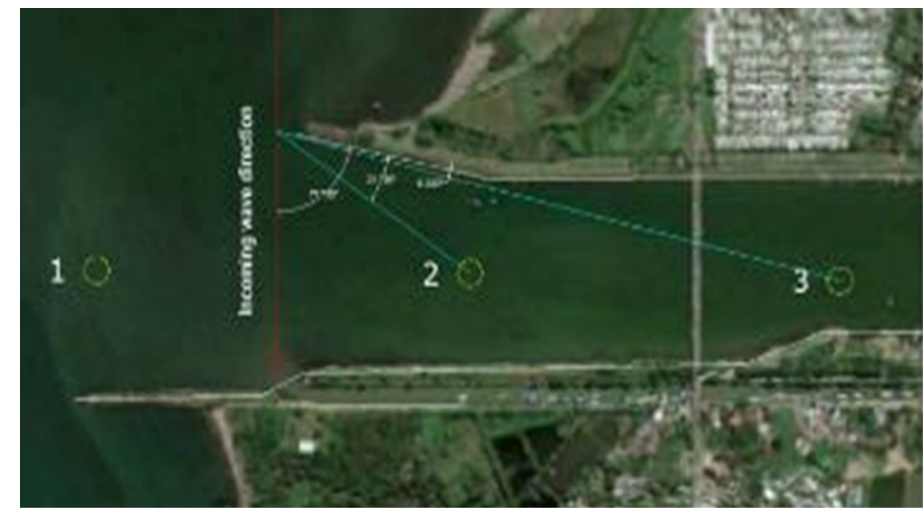

Figure 10. Inspection points of wave diffraction from north direction

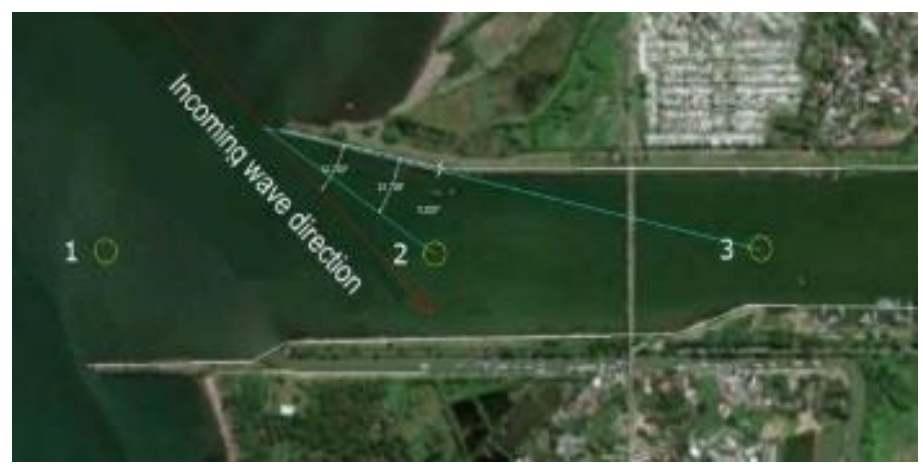

Figure 11. Inspection points of wave diffraction from northwest direction

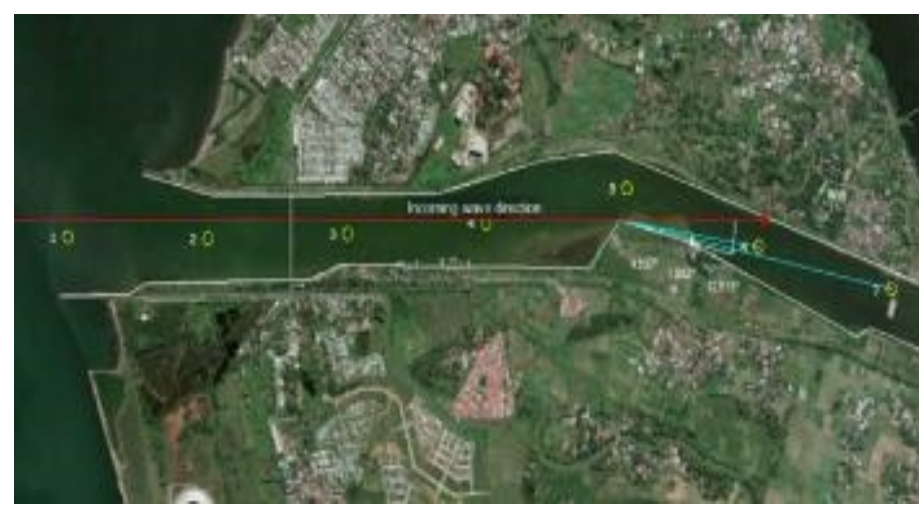

Figure 12. Inspection points of wave diffraction from west direction 


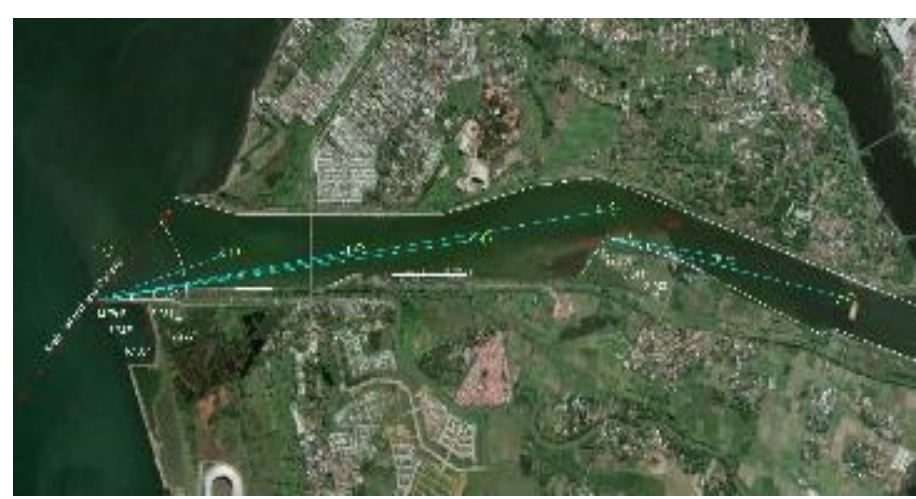

Figure 13. Inspection points of wave diffraction from southwest direction

The results of wave diffraction analysis for several parameters of average depth $d$, wavelength $L$, diffraction coefficient $K^{\prime}$, distance from obstacle to point of view $r$, height of wave at point of view $H_{A}$, height of wave at initial $H_{P}$, angle between obstacle and line of link to point of view $\beta$, Angle of wave propagation direction $\theta$, can be seen in the Table 5 until Table 8

Table 5. Wave diffraction from north direction

\begin{tabular}{cccccccccc}
\hline Point & $\mathbf{d}$ & $\mathbf{L}$ & $\mathbf{r}$ & $\mathbf{r} / \mathbf{L}$ & $\boldsymbol{\theta}$ & $\boldsymbol{\beta}$ & $\mathbf{K}^{\prime}$ & $\mathbf{H}_{\mathbf{P}}$ & $\mathbf{H}_{\mathbf{A}}$ \\
\hline 1 & 2.7 & 21 & 0 & 0 & 0 & 0 & 0.00 & 0.55 & 0.00 \\
2 & 2.7 & 21 & 381 & 18 & 78 & 22 & 0.13 & 0.55 & 0.07 \\
3 & 2.7 & 21 & 947 & 44 & 78 & 0 & 0.08 & 0.55 & 0.04 \\
4 & 2.7 & 21 & 0 & 0 & 0 & 0 & 0.00 & 0.55 & 0.00 \\
5 & 2.7 & 21 & 0 & 0 & 0 & 0 & 0.00 & 0.55 & 0.00 \\
6 & 2.7 & 21 & 0 & 0 & 0 & 0 & 0.00 & 0.55 & 0.00 \\
7 & 2.7 & 21 & 0 & 0 & 0 & 0 & 0.00 & 0.55 & 0.00 \\
\hline
\end{tabular}

Table 6. Wave diffraction from northwest direction

\begin{tabular}{cccccccccc}
\hline Point & $\mathbf{d}$ & $\mathbf{L}$ & $\mathbf{r}$ & $\mathbf{r} / \mathbf{L}$ & $\boldsymbol{\theta}$ & $\boldsymbol{\beta}$ & $\mathbf{K}^{\prime}$ & $\mathbf{H}_{\mathbf{P}}$ & $\mathbf{H}_{\mathbf{A}}$ \\
\hline 1 & 2.7 & 38 & 0 & 0 & 0 & 0 & 0 & 0.55 & 0.00 \\
2 & 2.7 & 38 & 381 & 10 & 33 & 22 & 0.54 & 0.55 & 0.29 \\
3 & 2.7 & 38 & 947 & 25 & 33 & 0 & 0.20 & 0.55 & 0.11 \\
4 & 2.7 & 38 & 0 & 0 & 0 & 0 & 0 & 0.55 & 0.00 \\
5 & 2.7 & 38 & 0 & 0 & 0 & 0 & 0 & 0.55 & 0.00 \\
6 & 2.7 & 38 & 0 & 0 & 0 & 0 & 0 & 0.55 & 0.00 \\
7 & 2.7 & 38 & 0 & 0 & 0 & 0 & 0 & 0.55 & 0.00 \\
\hline
\end{tabular}

DOI : http://dx.doi.org/10.31963/intek.v7i1.2103
Table 7. Wave diffraction from west direction

\begin{tabular}{cccccccccc}
\hline Point & $\mathbf{d}$ & $\mathbf{L}$ & $\mathbf{r}$ & $\mathbf{r} / \mathbf{L}$ & $\boldsymbol{\theta}$ & $\boldsymbol{\beta}$ & $\mathbf{K}^{\prime}$ & $\mathbf{H}_{\mathbf{P}}$ & $\mathbf{H}_{\mathbf{A}}$ \\
\hline 1 & 2.7 & 45 & 0 & 0 & 0 & 0 & 0 & 0 & 0.00 \\
2 & 2.7 & 45 & 0 & 0 & 0 & 0 & 0 & 0 & 0.00 \\
3 & 2.7 & 45 & 0 & 0 & 0 & 0 & 0 & 0 & 0.00 \\
4 & 2.7 & 45 & 0 & 0 & 0 & 0 & 0 & 0 & 0.00 \\
5 & 2.7 & 45 & 0 & 0 & 0 & 0 & 0 & 0 & 0.00 \\
6 & 2.7 & 45 & 613 & 14 & 13 & 5 & 0.35 & 2.09 & 0.73 \\
7 & 2.7 & 45 & 1207 & 27 & 13 & 2 & 0.35 & 2.09 & 0.73 \\
\hline
\end{tabular}

Table 8. Wave diffraction from southwest direction

\begin{tabular}{cccccccccc}
\hline Point & $\mathbf{d}$ & $\mathbf{L}$ & $\mathbf{r}$ & $\mathbf{r} / \mathbf{L}$ & $\boldsymbol{\theta}$ & $\boldsymbol{\beta}$ & $\mathbf{K}^{\mathbf{1}}$ & $\mathbf{H}_{\mathbf{P}}$ & $\mathbf{H}_{\mathbf{A}}$ \\
\hline 1 & 2.7 & 39 & 0 & 0 & 0 & 0 & 0 & 2.26 & 0.00 \\
2 & 2.7 & 39 & 610 & 16 & 44 & 15 & 0.15 & 2.26 & 0.34 \\
3 & 2.7 & 39 & 1219 & 31 & 44 & 8 & 0.15 & 2.26 & 0.34 \\
4 & 2.7 & 39 & 1829 & 47 & 44 & 6 & 0.15 & 2.26 & 0.34 \\
5 & 2.7 & 39 & 2438 & 62 & 44 & 7 & 0.15 & 2.26 & 0.34 \\
6 & 2.7 & 39 & 610 & 16 & 22 & 6 & 0.24 & 0.34 & 0.08 \\
7 & 2.7 & 39 & 1219 & 31 & 22 & 3 & 0.24 & 0.34 & 0.08 \\
\hline
\end{tabular}

From Table 5 until Table 8, it can be seen that the value of wave diffraction coming from the north direction at inspection point 2 is $0.07 \mathrm{~m}$ and at inspection point 3 is $0.04 \mathrm{~m}$. The value of wave diffraction coming from the northwest direction at inspection point 2 is $0.29 \mathrm{~m}$ and at inspection point 3 is $0.11 \mathrm{~m}$. The value of wave diffraction coming from the west direction at inspection point 6 is $0.73 \mathrm{~m}$ and at inspection point 7 is $0.73 \mathrm{~m}$. Lastly, the wave diffraction coming from the southwest direction occurs at inspection point $2,3,4,5,6$, and 7 , with the wave diffraction at point $2,3,4,5$ is $0.34 \mathrm{~m}$ and at point 6 and 7 is $0.08 \mathrm{~m}$.

\section{Conclusion}

1. The tidal propagation can only reach up to 3 inspection points, reaching a propagation length from the estuary at approximately 1220 meter.

2. The wave diffraction is due to the presence of jetty structure and the shape of the mouth of the estuary, which allows it to turn around the end of the obstacle and enter the protected area behind it. Waves coming in from the north and northwest are being diffracted down southern bank of the river. Waves coming from 
the west and southwest will be diffracted to the north bank of the river

3. The results in this study could be compared with tidal numerical models and wave diffraction in the Jeneberang River estuary for subsequent research.

\section{References}

[1] A. Purwandana, "Kajian Percampuran Vertikal Massa Air dan Manfaatnya (Study of Vertical Mixing of Water Mass and Its Benefits)," Oseana, vol. 38, no. 3, pp. 09-22, 2013.

[2] T. Jansen, "Sedimentasi, Salinitas dan Intrusi Air Laut pada Profil Muara Sungai Chikugo, Japan (Sedimentation, Salinity and Seawater Intrusion in Japan's Chikugo Estuary)," Jurnal Ilmiah Media Engineering, vol. 6, no. 2, Jul. 2016.

[3] B. Triatmodjo, Teknik Pantai (Coastal Engineering). Beta Offset, Yogyakarta, 1999.

[4] H. Surbakti, "Karakteristik Pasang Surut dan Pola Arus di Muara Sungai Musi, Sumatera Selatan (Tidal Characteristics and Flow Patterns at the Musi River Estuary, South Sumatra)," Jurnal Penelitian Sains, vol. 15, no. 1, pp. 35-39, 2012.

[5] K. R. Dyer, Coastal and Estuarine Sediment Dynamics. Chichester; New York: Wiley, 1986.

[6] V. T. Buchwald, "The diffraction of tides by a narrow channel," Journal of Fluid Mechanics, vol. 46, no. 3, pp. 501-511, Apr. 1971, doi: 10.1017/S0022112071000661.

[7] G. Dodet, X. Bertin, N. Bruneau, A. B. Fortunato, A. Nahon, and A. Roland, "Wave-Current Interactions In A WaveDominated Tidal Inlet," Journal of Geophysical Research: Oceans, vol. 118, no. 3, pp. 1587-1605, 2013, doi: $10.1002 /$ jgrc. 20146

[8] Y. Arafat, M. S. Pallu, F. Maricar, and R. T. Lopa, "Hydrodynamics and Morphological Changes Numerical Model of the Jeneberang Estuary," International Journal of Innovative Research in Advanced Engineering (IJIRAE), vol. 3, no. 8, pp. 21-29, 2016.

[9] B. Bakri, A. Sumakin, Y. Widiasari, and M. Ihsan, "Analysis of Water Salinity Distribution Pattern in The Estuary of Jeneberang River by Using ArcGIS, Fourth International Symposium on Infrastructure Development," presented at the he 3rd International Conference on Civil and Environmental Engineering 2019, Gowa, vol. 419. 2019.
[10] R. Karamma, M S. Pallu, M. A, Thaha, M. P. Hatta,"Stratification Model of Seawater Mass Structure at the Estuaries of Jeneberang River and Tallo River and the influences to current pattern in Makassar Coastal Areas," in IOP Conference Series: Earth and Environmental Science, Gowa, vol. 419. 2019.

[11] B. Bakri, S. Pallu, R. Lopa, M. Akbar, M. Ihsan, and Y. Arai, "Flow Velocity Distribution Analysis on Free Intake Structure and Its Influence to Intake Capacity," in International Conference on Engineering and Technology Development (ICETD), 2017.

[12] M. P. Hatta, V. A. Ilham, and E. Aprianti, "Simulation of the Effect of Flow Velocity on Floating Sediment Concentration at the Jeneberang River Estuary with the Nays2DH Model," International Journal of Engineering Research and Applications (IJERA), vol. 9, no. 11, pp. 1-7, 2019.

[13] R. Karamma and A. S. Sukri, "Pemodelan Pasang Surut terhadap Surf Zone Menggunakan Surfer, Fortran C++ dan GIS pada Pantai Kota Makassar (Modelling of Tides in Surf Zone on The Beach of Makassar City Using Surfer, Fortran C ++ And GIS)," SemanTIK, vol. 4, no. 2, pp. 47-56, Dec. 2018.

[14] United States Army Corps of Engineers, Shore protection manual, 4th ed. Vicksburg, Miss, Washington, DC: Dept. of the Army, Waterways Experiment Station, Corps of Engineers, Coastal Engineering Research Center, 1984.

[15] United States Army Corps of Engineers, Coastal engineering manual. 2002.

[16] T. Arifin, Y. Yulius, and M. F. A. Ismail, "Kondisi Arus Pasang Surut Di Perairan Pesisir Kota Makassar, Sulawesi Selatan (Tidal Current Conditions in Coastal Area of Makassar, South Sulawesi)," DEPIK Jurnal Ilmu-Ilmu Perairan, Pesisir dan Perikanan, vol. 1, no. 3, Dec. 2012, doi: 10.13170/depik.1.3.113.

[17] R. Karamma, "Analysis of Coastal Sediment Transport in Estuary of Jeneberang and Tallo River Caused by Waves against Coast of Makassar," in ICMID, Kendari, 2018. 